\title{
EFFECT OF SOME VEGETABLE OILS IN ENHANCING THE POTENCY OF BIOINSECTICIDES AGAINST THE COTTON LEAFWORM
}

\author{
ABD EL-HAFEZ, HANAN, ELHAM F. ABD EL- RAHIM and E.M. MOHAMED
}

Plant Protection Res. Inst., ARC, Dokki, Giza.

(Manuscript received 2 June 2013)

\begin{abstract}
Field investigation revealed that emulsified oils of Cotton seed, Sesame and Soybean enhanced the activity and persistence of the bio-product, Spinosad 24SC, Dipel $2 \times 6.4 \mathrm{Wp}$ and Protecto $9.4 \mathrm{Wp}$ against the $2^{\text {nd }}$ and $4^{\text {th }}$ instar larvae of the cotton leafworm, S. littoralis (Boisd).Physico-chemical properties (Suspensibility, Viscosity and $\mathrm{pH}$ value) of tested biocides either alone or in combination with vegetable oils were also determined under field dilution rates (200 Lw/fed).The obtained results clearly showed that , all the candidate oils were compatible with the tested bioinsecticides, they gave homoganic suspension and increased their viscosity and $\mathrm{pH}$ value. Sesame oil scored the highest increase in both viscosity and $\mathrm{pH}$ value. The data proved that all the tested oils increased both initial kill and residual activity of candidate biocides. The most evaluated promising synergism, occurred when Sesame oil at $0.3 \%$ mixed with full recommended doses of Spinosad, Dipe $12 x$ and Protecto, it showed a remarkable effect in increasing both initial and residual effect after time intervals i.e. zero, 3,7,9 and 14 days post application. It caused $100 \%$ larval mortality at the initial time (zero-day) against both $2^{\text {nd }}$ and $4^{\text {th }}$ instar larvae of $S$. littoralis, as compared with biocides alone. Also, residual activity was increased from $49.9,30.15$ and $24.34 \%$ to $95.05,85.13$ and $77.25 \%$, respectively against $2^{\text {nd }}$ instar and from $30.15,12.77$ and $12.5 \%$ to $79.75,49.15$, and $40.4 \%$ against $4^{\text {th }}$ instar larvae of $S$. littoralis after 14 days post application. In addition, that all the treated larvae were biologically affected by the three tested biocides alone or in combination with the three vegetable oils. The effect varied according to the larval instar, tested biocide and added oil. Therefore, the treatment of larvae were resulted in decrease the pupation and adult emergence \%,pupal weight, adult longevity, fecundity, eggs hatchability and increased the larval and pupal duration and induced the larval,pupal, adult malformations $\%$ and shifted the sex ratios\% of males and females, as compared to that of control. The synergistic effect may be due to the addition of vegetable oil that could increase the viscosity of bio-insecticides spray solution. This would increase the deposit on the treated plant leaves, reduce the drift and increase the persistence and improving the target pest control.Also, addition of vegetable oils inhibits respiration and thus, in turn may synergize the toxicity of Spinosad that can act on the nervous system.Also, to change $\mathrm{pH}$ of the gut, being more alkaline and thus enhancing the endotoxin breakdown and release of toxic fragments of Dipel $2 x$ and Protecto.
\end{abstract}




\section{INTRODUCTION}

The Egyptian cotton leafworm, Spodoptera. Littoralis (Boisd) was and still now considered one of the most serious phytophagous pests of Egyptian cotton. Larvae attack other wide range of field and horticulture crops such as vegetables, ornamentals and orchards. Intensive use of broad-spectrum chemical insecticides for controlling of $S$. littoralis usually leads to adverse effects on non-target organisms and development of high levels of resistance in pests to organophosphates, carbamates and pyrethroids. The hazards of pesticides and development of resistance to chemical insecticides in the cotton leafworm, $S$. littoralis, necessitates the use of safe and effective insect pathogens such as microbial insecticides.

Microbial insecticides such as Bacillus thuringiensis have been reported to provide inadequate control of $S$. littoralis and prime candidates for use in Integrated Pest Management Programme (IPM).They have high pathogenicity for target pests. Safe for most non-target organisms, and have good integration with other pest control methods (Ibrahim et al.2010).

Biorational control agents, based on naturally derived products or compounds that disrupt the physiological processes of insects have attracted particular interest.Spinosad is the naturally occurring metabolite derived by fermentation of the actionomycete, Saccharopolyspora spinosa Mertz \& Yao and it has rapid contact and ingestion activity in insects causing excitation of nervous system leading to cessation of feeding and paralysis. This product is particularly effective against Lepidoptera, Diptera and Thysanoptera. The mode of action of this compound involves the postsynaptic nicotinic acetylcholine receptor and the gama amino btric Acid (GABA) receptor. Spinosad has contact activity on all life stages, as well as stomach poison. It is known that most microbial insecticides have a very short residual activity and the persistence of spores showed an obvious reduction after few days of weathering in Egyptian cotton fields. Degradation of Spinosad in the environment occurs mainly by photo-degradation and microbial degradation (Thompson \& Hutchins, 1999). Also most Bt formulations have a very short residual activity, in cotton fields in Egypt has been found that the persistence of spores of B.t showed an obvious reduction after few days of weathering and decouy in its viability was progressively correlated with the time of exposure, because it has a very short effective residual life. The pathogen is not mobile and cannot escape under the unfavorable condition. Ultraviolet radiation seems to be the dominant factor affecting the spores viability (Morris et al., 1996). Therefore, the aim of the current study was to investigate how vegetable oils could 
enhance the residual activity of tested microbial insedicides for controlling $S$. littoralis under field condition.

\section{MATERIALS AND METHODS}

I- Insect: Sufficient egg-masses of cotton leafworm, $S$. littoralis were collected from Sids Agricultural Res.Station, Beni-Sueif Governorate during 2012 cotton season. Larvae were reared under laboratory conditions at $25 \pm 2 \mathrm{C}^{\circ}$ and $60 \pm 5 \%$ R.H. The $2^{\text {nd }}$ and $4^{\text {th }}$ instar larvae were used in all field experiments.

\section{ח-Bioinsecticides:}

1-Dipel 2x: $6.4 \%$ W.P.based on Bacillus thuringiensis is subsp. Kurstaki (32,000IU/mg).Produced by Abbott laboratories, North Chicago.U.S.A.

2-Protecto:9.4\%W.P.based on Bacillus thuringiensis is subsp. Kurstaki, it contains 9.4\% Lepidopteran active toxin produced by the Plant Protection Res.Inst.A.R.C.

3-Spinosad(Spintor $\mathbf{2 4 \% S C}$ ) is a natural bio-product formulation of a mixture of two natural metabolites,Spinosyn A (C41H65NO10) and D (C42H67NO10).It was used at a rate of $50 \mathrm{~cm}^{3} /$ Feddan produced by Dow Agrosciences Chemical Co.

\section{ш-Vegetable oils:}

a-Cotton seed oil, contains about $25 \%$ saturated acids, $25 \%$ oleic acid and $50 \%$ linoleic acid, supplied by Alexandria company for oils and Detergents.

b-Sesame oil, contain $0.4-1.1 \%$ Sesamin, $0.3-0.6 \%$ Sesamolin and only traces of Sesamol, supplied by EL-SalamCo.for oils.

c-Soybean oil contains about 2.3\% Stearic, $8 \%$ Vicinoleic and 3.8\% Saturated fat, supplied by EL-SalamCo.for oils.

\section{IV-Surfactant agent:}

Emulsifier (El-Sisi6) produced by Central Agricultural Pesticides Laboratory, ARC, was used at $0.3 \%$.

\section{V- Physico-chemical properties}

Physico-chemical tests were studied for the tested bioinsecticides alone and their combinations with vegetable oils.Suspensibility assay of the tested bioinsecticides alone and their mixtures with oils was carried out to select the best mixture showing the physical compatibility according to WHO specifications (Anonymous, 1979) under field dilution rate (200Lwater/fed).The $\mathrm{PH}$ value was measured at $20 \mathrm{C}^{\circ}$ by using $\mathrm{PH}-$ meter, While viscosity was measured by using Ostwold viscometer. 


\section{VI- Semi-field experiments:}

Were performed in cotton fields in Sids Agric.Res.Station, Beni-Suief Governorate during June 2012cotton seasone.To evaluated the initial and residual activity of candidate bioinsecticides alone and their mixtures with vegetable oils, the biocides, Diple 2x, Protecto and Spinosad were applied at their recommended rates $200 \mathrm{gm}, 300$ $\mathrm{gm}$ and $50 \mathrm{~cm}^{3} / \mathrm{fed}$, respectively and their combinations with $0.3 \%$ vegetable oils. All crude tested oils were diluted in $0.3 \%$ emulsifier (EL-Sisi6) to prepare aqueous emulsions. The treatments were sprayed on cotton plants variety Giza 80 using a solo motor under field dilution at rate (200 Lwater/fed). Samples of treated cotton leaves randomizely collected from each treatment at different time intervals i.e. Zero, 3,7,9 and 14 days after application. Then leaves were transferred to the laboratory and offered to $2^{\text {nd }}$ and $4^{\text {th }}$ instar larvae of $S$. littoralis. Five replicates (ten larvae/replicate) were fed on treated leaves for $48 \mathrm{hrs}$., then the alive larvae fed on untreated cotton leaves until pupation. Other five replicates were fed on untreated cotton leaves as check. The treated larvae were examined daily to determine the mortality percentages. The larval mortality was recorded and corrected using Abbotts'formula (1925). Different biological aspects such as larval, pupal duration, pupation and adult emergence percentages and adult fecundity, longevity and sex ratio and eggs hatching percentage, larval, pupal and adult malformations were also determined.

\section{VII-Statistical analysis:}

The data of the biology were statically calculated through Excel for windows computer program to determine the F-value, P-value and L.S.D (least significant difference at 0.05 or 0.01 freedom degrees.

\section{RESULTS AND DISCUSSION}

\section{1-Effect of vegetable oils on the physico-chemical properties of tested biorational product:}

Physico-chemical properties of Spinosad, Dipel 2x and Protecto (Suspensibility, Viscosity and PHvalue) were measured at total field application volume rate (200LW/fed.) either alone or in combination with the tested plant oils. The results clearly showed that, all the evaluated oils were almost compatible with tested bioinsecticides (Table 1). They gave good suspension without any oil separation or precipitation at the bottom of cylinder after half an hour.Suspensibility was considered as a limiting factor for successful mixtures and would be an important guide for the physical compatibility of the mixed material [Anonymous, 1979 WHO specification]. Viscosity of biocides were also increased (Table 1 ) when they were mixed with $0.3 \%$ 
vegetable oils $+0.3 \%$ emulsifier. Sesame oil gave the highest increase in viscosity 13.59Mps when combined with Spinosad in comparison with Spinosad alone 10.08 Mps, followed by cotton seed oil 13.33 Mps. Also, Sesame oil gave the highest increase in viscosity when mixed with Dipel $2 x$ and Protecto, it gave 11.28 and 13.5 Mps as comparison with Dipel $2 x$ and Protecto alone 10.24 and 10.35 Mps respectively, followed by cotton seed oil 11.2 and 13.33 Mps, respectively. Whereas, Soybean oil revealed the least activity in increasing the viscosity of the tested bioinsecticides. The increase in viscosity of spray solutions would increase the deposit on the treated plant leaf surfaces, reduce the drift and increase the persistence of insecticides[Bode et al.,1976].

Table 1. Physico-chemical properties of Spinosad, Dipel 2x, Protecto and their combinations with tested vegetable oils under field dilution rates.

\begin{tabular}{|l|c|c|c|c|}
\hline Combination & Rate/Feddan & $\begin{array}{c}\text { Precipitation } \\
\text { (M1) }\end{array}$ & $\begin{array}{c}\text { Viscosity } \\
\text { Mps }\end{array}$ & PH value \\
\hline Spinosad 24\%Sc & $50 \mathrm{~cm}^{3}$ & 0.0 & 10.08 & 6.95 \\
\hline S+Cotton seed oil & $50 \mathrm{~cm}^{3}+0.3 \%$ & 0.0 & 13.33 & 7.55 \\
\hline S+Sesame oil & $50 \mathrm{~cm}^{3}+0.3 \%$ & 0.0 & 13.59 & 7.75 \\
\hline S+Soybean oil & $50 \mathrm{~cm}^{3}+0.3 \%$ & 0.0 & 12.59 & 7.21 \\
\hline Dipel 2x 6.4\% Wp & $200 \mathrm{gm}$ & 0.0 & 10.24 & 6.6 \\
\hline D+ Cotton seed oil & $200 \mathrm{gm}+0.3 \%$ & 0.0 & 11.20 & 7.32 \\
\hline D+ Sesame oil & $200 \mathrm{gm}+0.3 \%$ & 0.0 & 11.28 & 7.26 \\
\hline D+ Soybean oil & $200 \mathrm{gm}+0.3 \%$ & 0.0 & 11.15 & 7.22 \\
\hline Protecto 9.4 Wp & $300 \mathrm{gm}$ & 0.0 & 10.35 & 6.8 \\
\hline P+ Cotton seed oil & $300 \mathrm{gm}+0.3 \%$ & 0.0 & 13.33 & 7.85 \\
\hline P+ Sesame oil & $300 \mathrm{gm}+0.3 \%$ & 0.0 & 13.5 & 7.85 \\
\hline P+ Soybean oil & $300 \mathrm{gm}+0.3 \%$ & 0.0 & 11.59 & 7.80 \\
\hline
\end{tabular}

S: Spinosade

* Mps=Mill poase $\quad$ D: Dipel $2 x$

$$
\text { P: Protecto }
$$

Vegetable oils such as cottonseed or soybean oil were useful for improving the properties of teste bio-insecticides formulations when ultra-low volume application is used for regulating the number of drops and their volume median diameters, which were in many cases playing an important role for increasing the efficacy of insecticides in aerial application. Spray oils increase toxicity, penetration and persistence of contact insecticides and serve as a useful addition to various insect control agents. Vegetable oils may increase the uptake of the toxicant by the insect or reduce its evaporation dissipation or both. 
In some insect species, oils inhibit respiration and this, in turn may synergize the toxicity of insecticides that act on the nervous system. Abhilash and Patil (2006) reported that vegetable and mineral oils increased the adhesion, wetting and spreading properties of pesticides on the surface of the targets, decreasing pesticide loss and improving pest control. Also, data in Table (1) showed that PH values of Spinosad, Dipel $2 x$ and Protecto were increased from 6.95,6.6 and 6.8 to 7.55,7.32 and 7.85 , respectively, when combined with cotton seed oil and were increased to 7.75,7.26 and 7.85 when mixed with Sesame oil and to 7.21,7.22 and 7.8 with soybean oil.Spinosad is stable at PH ranging between 5-8 (Thompson\& Hutchins ,1999). The activity of delta endotoxin of Bacillus thuringiensis (Bt) preparation increased as alkalinity increased from 8 to 10 and then declined rapidly at $\mathrm{PH}>10$ (Gringorten et al,1992).

\section{2-The initial and residual effects of the tested bioinsecticides and their combinations with vegetable oils under field conditions.}

The initial and residual effect of biorational products alone and their mixtures with $0.3 \%$ plant oils at indicating time intervals i.e. zero, 3, 7, 9 and 14 days post application against $2^{\text {nd }}$ and $4^{\text {th }}$ instar, larvae of $S$. littoralis are shown in Table (2). Data revealed that all the evaluated oils increased initial kill and residual activity of tested biocides. Cotton seed, Sesame and Soybean oils at $0.3 \%$ increased mortalities when combined with Spinosad,Dipel $2 x$ and Protecto at recommended dose, they caused $100 \%$ larval mortalities against $2^{\text {nd }}$ and $4^{\text {th }}$ instar at the initial time interval (zero-day) except with cotton and soybean oils when they mixed with protecto, as compared to bioinsecticides alone $93.6,87.5$ and $80.85 \%$, respectively on $2^{\text {nd }}$ instar and $79.9,65$ and $60 \%$, respectively, on $4^{\text {th }}$ instar.Also, tested vegetable oils increased residual activity of tested biorational products after 14 days post application. Mean residual effects of Spinosad, Dipel $2 x$ and Protecto were increased when mixed with $0.3 \%$ cotton seed, Sesame and Soybean oils from $49.9,30.15$ and $24.34 \%$ to 92.5 , $95.05,89,76.25,85.13,70,70,77.25$ and $59.58 \%$, respectively, against $2^{\text {nd }}$ instar larvae of S.littoralis and from $30.15,12.77$ and $12.5 \%$ to $75,79.75,68.5,39.28,49.15,32.03,37.4$, 40.4 and 31.65 , respectively, against $4^{\text {th }}$ instar larvae of $S$. littoralis as illustrated in figs. $1,2,3,4$ and 5 .

It could be concluded that the initial kill but residual effect of the tested bioinsecticides markedly increased by using vegetable oils at $0.3 \%$ in combination with full recommended doses of Spinosad,Dipel $2 x$ and Protecto.Sesame oil was the most synergistic additive, it showed a remarkable effect in enhancing biocides potency followed by cotton seed oil, while soybean oil came at last in order in enhancing the potency of tested bioinsecticides. The synergistic effects of vegetable oils with 
Spinosad,Dipel $2 x$ and Protecto may be due to the addition of such oils which increased the viscosity and $\mathrm{PH}$ value of biocides spray solution, this would increased the deposit on the treated plant leaves, reduce the drift and increase the persistence of biocides and protect the spores from UV radiation [Bode et al.,1976].

It is known that most bio-insecticides have short residual activity and persistence of components or spores showed an obvious reduction after few days of weathering in Egyptian cotton fields. Degradation of Spinosad in the environment occurs mainly by photo and microbial degradation (Thompson and Hutchins, 1999).In previous studies, Spinosad showed moderately initial and residual effects 58.7 and $75.95 \%$, when tested single at $50 \mathrm{~cm} /$ feddan against $S$. littoralis(Abdel Mageed et al., 2006).Also, residual activity of Spinosad on cotton plants was up to7 days with $40 \%$ mortality on Agrotis ipsilon $2^{\text {nd }}$ instar larvae (Mahmoud, 2004).Also, Bacillus thuringiensis(Bt) formulations have a very short residual activity, in cotton fields in Egypt has been found that the persistence of spores showed an obvious reduction after few days of weathering, the pathogen is not mobile and cannot escape under the unfavorable conditions[Moar et al.,1986 and Morris et al.,1996].In order to increase Bt potency, the conditions prevailing insect midgut must be modified by incorporation of some selected compounds. This compounds must be non-toxic to man or animal, possess no harmful effect on plants, biodegradable and commonly available at low price (EL-Moursy et al, 1996).

Vegetable and mineral oils increased the adhesion, wetting and spreading properties of pesticides on the surface of Targets, decreasing pesticides loss and improving pest control (Abhilash and Patil, 2006). Obtained results agree with those of Mahmoud (2004) who reported that Spinosad when mixed with tagetes oil $(50 \mathrm{~cm} / \mathrm{fed}$ $+500 \mathrm{~cm} / \mathrm{fed}$ ) produced high reduction (90.46 and $82.46 \%$ ) for pink and spiny bollworms. In addition, Temerak (2003) stated that Spinosad $24 \%$ Sc at $50 \mathrm{~cm} / \mathrm{fed}$ when mixed with $1 \mathrm{~L} /$ fed mineral oil showed best reduction in both cotton bollworm, especially E.insulana.Also, it showed $92 \%$ reduction in both pink and spiny bollworm as comparison with Spinosad alone $77 \%$.Adding mineral oil enhancing Spinosad performance and was significantly better than Spinosad alone. In addition,Grovena et al. (2002)found that Spinosad when mixed at 7.5,10,12.5 and $15 \mathrm{ml} / 100 \mathrm{~L}$ water + $250 \mathrm{ml} / 100 \mathrm{~L}$ water of mineral or vegetable oil showed lower $\%$ of damaged leaves by phyllocnistis citrella after 21 days of spraying. 
Table 2. Initial and residual activity of the tested bioinsecticides and their combination with vegetable oils against $S$. littoralis treated as $2^{\text {nd }}$ and $4^{\text {th }}$ instar larvae, under field conditions.

\begin{tabular}{|c|c|c|c|c|c|c|c|c|c|c|c|c|}
\hline \multirow[t]{5}{*}{ Combination } & \multicolumn{10}{|c|}{ Larval mortality\% after indicating time interval(days) } & \multirow{2}{*}{\multicolumn{2}{|c|}{$\begin{array}{c}\text { Mean residual } \\
\text { Activity \% }\end{array}$}} \\
\hline & \multirow{2}{*}{\multicolumn{2}{|c|}{$\begin{array}{c}\text { Initial kill \% } \\
\text { (zero day) }\end{array}$}} & \multicolumn{8}{|c|}{ Residual activity \% } & & \\
\hline & & & \multicolumn{2}{|c|}{3 days } & \multicolumn{2}{|c|}{ 7days } & \multicolumn{2}{|c|}{9 days } & \multicolumn{2}{|c|}{14 days } & \multirow{3}{*}{$\begin{array}{l}2^{\text {nd }} \\
\text { instar }\end{array}$} & \multirow{3}{*}{$\begin{array}{l}4^{\text {th }} \\
\text { instar }\end{array}$} \\
\hline & $2^{\text {nd }}$ & $4^{\text {th }}$ & $2^{\text {nd }}$ & $4^{\text {th }}$ & $2^{\text {nd }}$ & $4^{\text {th }}$ & $2^{\text {nd }}$ & $4^{\text {th }}$ & $2^{\text {nd }}$ & $4^{\text {th }}$ & & \\
\hline & instar & instar & instar & instar & instar & instar & instar & instar & instar & instar & & \\
\hline Spinosad24SC & 93.6 & 79.90 & 68 & 51.66 & 52.78 & 40 & 42.2 & 22.2 & 36.6 & 6.7 & 49.9 & 30.2 \\
\hline S+cotton oil & 100 & 100 & 100 & 87.5 & 100 & 77.5 & 90 & 72.5 & 80 & 62.5 & 92.5 & 75 \\
\hline S+sesame oil & 100 & 100 & 100 & 90 & 100 & 87.5 & 92 & 77.5 & 88.2 & 64 & 95.1 & 79.8 \\
\hline Dipel $2 \times 6.4 \mathrm{Wp}$ & 87.5 & 65 & 43.48 & 20 & 36.96 & 13.3 & 10 & 5 & 0.0 & 0.0 & 30.2 & 12.8 \\
\hline $\mathrm{D}+$ cotton oil & 100 & 100 & 87.5 & 55 & 80 & 40 & 77.5 & 36.6 & 60 & 25.5 & 76.3 & 39.3 \\
\hline $\mathrm{D}+$ sesame oil & 100 & 100 & 92.5 & 60 & 90 & 55 & 82.5 & 45 & 75.5 & 36.6 & 85.1 & 49.2 \\
\hline $\mathrm{D}+$ soybean oil & 100 & 100 & 80 & 45 & 75 & 36.6 & 70 & 26.5 & 55 & 20 & 70 & 32.0 \\
\hline Protecto9.4Wp & 80.85 & 60 & 36.96 & 17.5 & 28.57 & 7.5 & 7.5 & 0.0 & 0.0 & 0.0 & 24.3 & 12.5 \\
\hline $\mathrm{P}+$ cotton oil & 100 & 93.6 & 85 & 45 & 77 & 42.5 & 62 & 36.6 & 56 & 25.9 & 70 & 37.4 \\
\hline P+ sesame oil & 100 & 100 & 90 & 50 & 82 & 45 & 73 & 36.6 & 64 & 30 & 77.3 & 40.4 \\
\hline Control & 0.0 & 0.0 & 0.0 & 0.0 & 0.0 & 0.0 & 0.0 & 0.0 & 0.0 & 0.0 & 0.0 & 0.0 \\
\hline
\end{tabular}




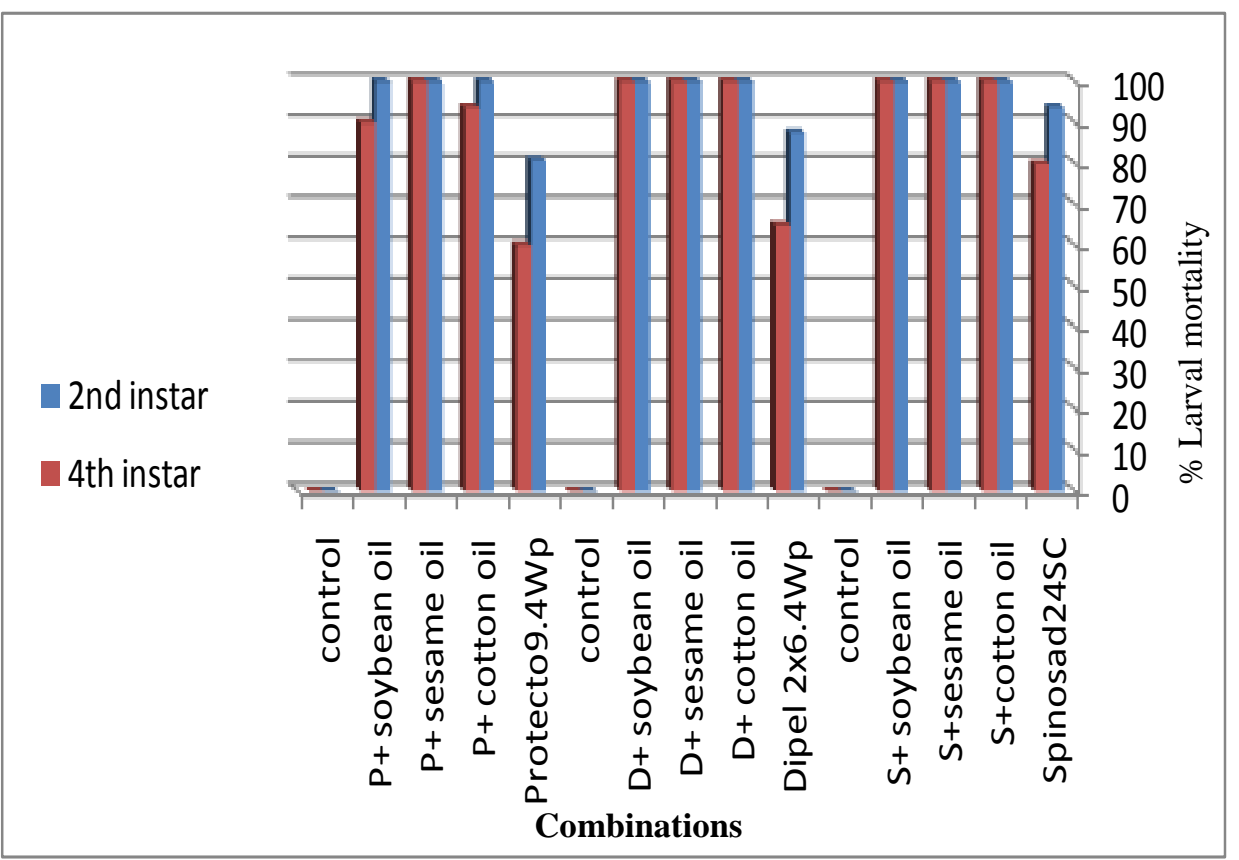

Fig.1. Initial activity (zero time) of the tested bioinsecticides and their combination with vegetable oils against $S$. littoralis treated as $2^{\text {nd }}$ and $4^{\text {th }}$ instar larvae, under field conditions

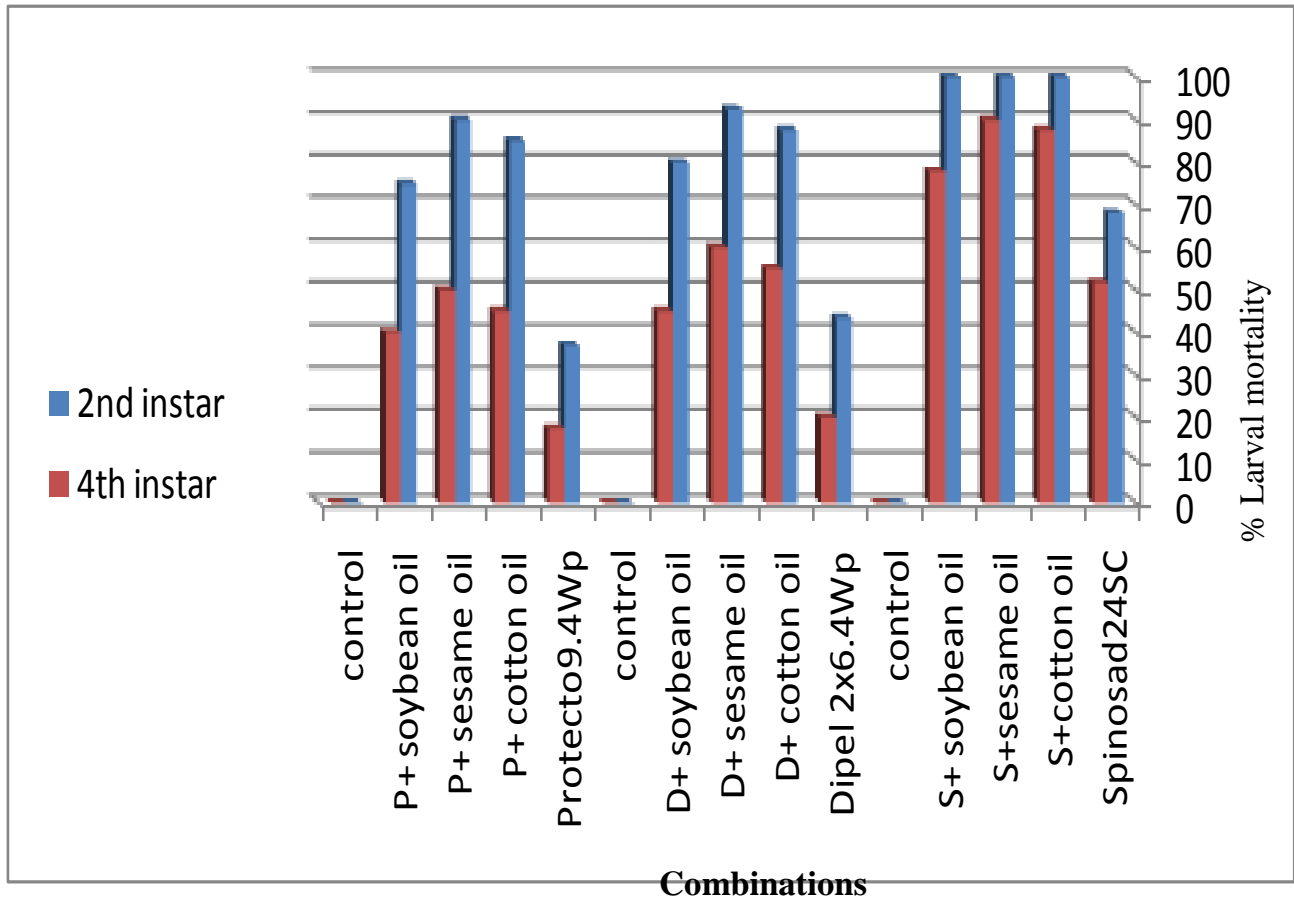

Fig.2. residual activity (after 3days) of the tested bioinsecticides and their combination with vegetable oils against $S$. littoralis treated as $2^{\text {nd }}$ and $4^{\text {th }}$ instar larvae, under field conditions 


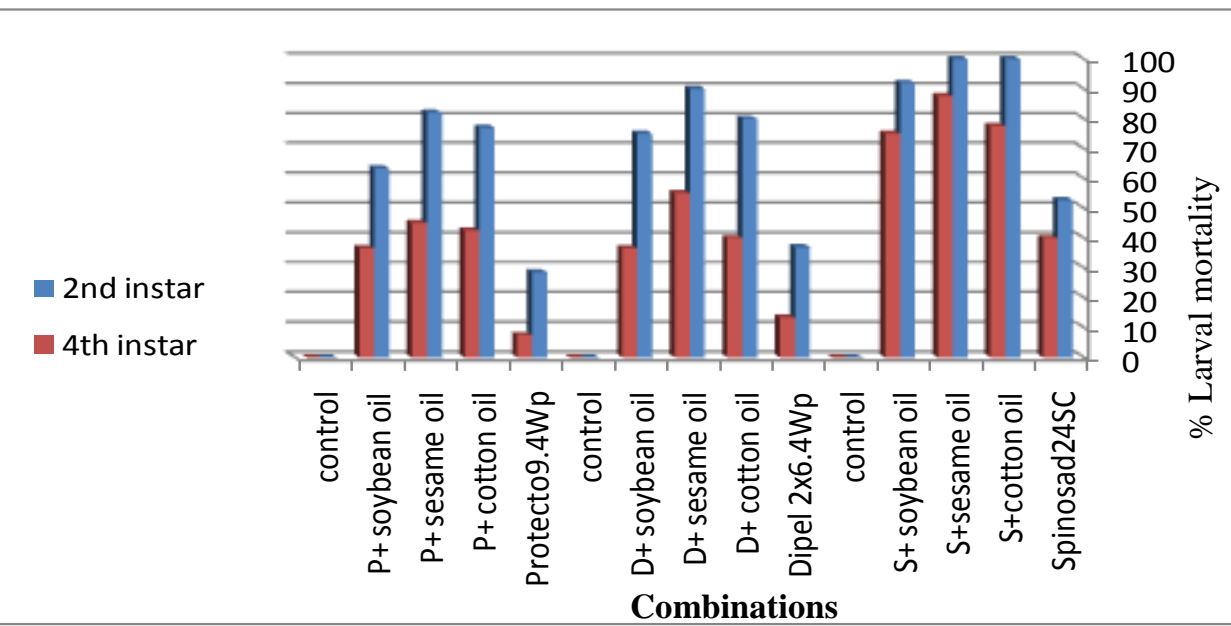

Fig.3. residual activity (after 7days) of the tested bioinsecticides and their combination with vegetable oils against $S$. littoralis treated as $2^{\text {nd }}$ and $4^{\text {th }}$ instar larvae, under field conditions

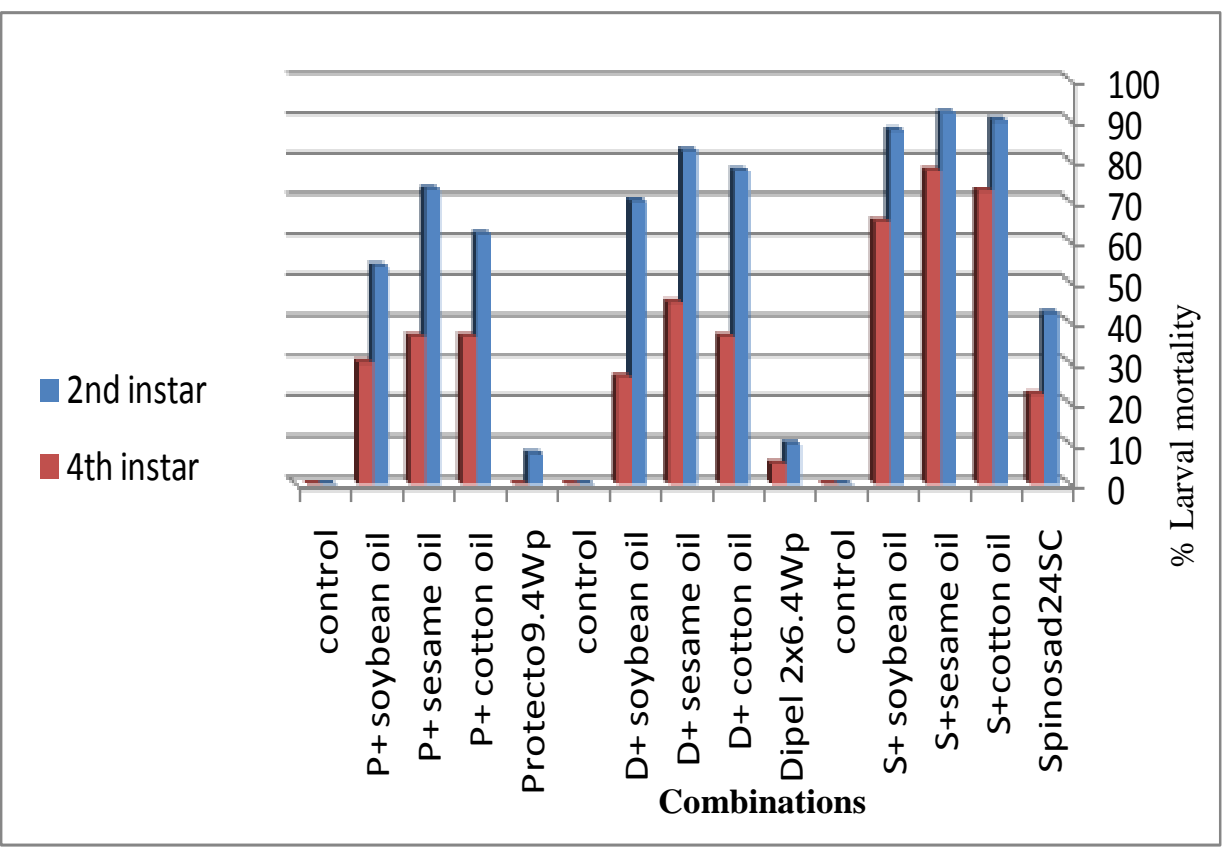

Fig.4. residual activity (after 9days) of the tested bioinsecticides and their combination with vegetable oils against $S$. littoralis treated as $2^{\text {nd }}$ and $4^{\text {th }}$ instar larvae, under field conditions 


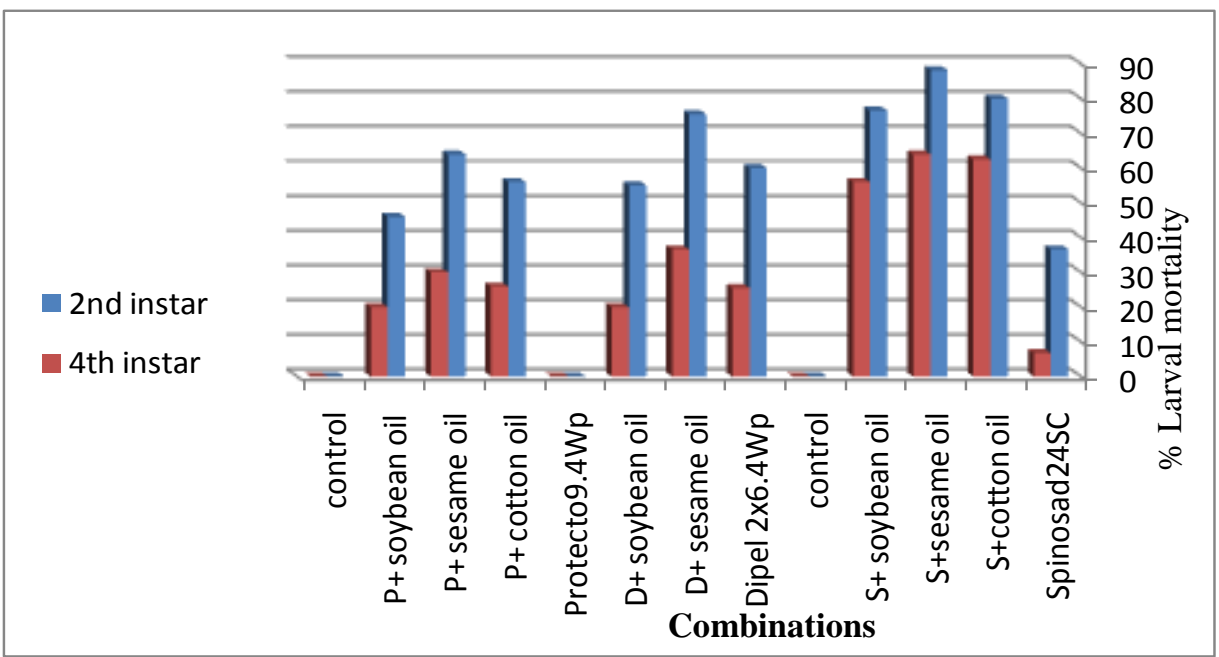

Fig.5. residual activity (after 14days) of the tested bioinsecticides and their combination with vegetable oils against $S$. littoralis treated as $2^{\text {nd }}$ and $4^{\text {th }}$ instar larvae, under field conditions.

Also, Abdel-Hafez and Abdel-Aziz (2010) indicate that emulsified oils of Tagetes, Sesame and (Soybean+ Sunflower) enhanced the potency and persistence of Spinosad 24Sc against $2^{\text {nd }}$ instar larvae of S.littoralis under laboratory condition. The most promising synergism, occurred when Spinosad was combined with $0.25 \%$ Targets oil, followed by $0.5 \%$ Sesame oil. Combination of Spinosad+Tagetes oil was $3.5,4.8$ and 4.3 times more toxic for the target insect pest than Spinosad alone after 48,72 and $168 \mathrm{hr}$ post exposure.

Formulation containing Soybean, Cotton seed and Corn oils may be useful as bases of spray adjuvant to increase the effectiveness of Bt used to control Tobacco budworm, Heliothis virescens and bollworm,Heliothis zea (Hafez et al.,1987).In addition,Robredo and Obama(1987) stated that using Soybean oil as carrier for Bt in ULV-applications increase the efficacy of the bacterial insecticide from 79.3 to $92.1 \%$ against Thaumetopaea pityocampa. Temerak (2003) and Turanili et al,(2012)found that combination of Dipel $2 x 50 \mathrm{gm} / 100$ litres $+250 \mathrm{ml}$ mineral oil gave the highest reduction on potato tuberworm, Phthorimaea operculella.Also, combination of Bt var. Kurstaki (Delfin), Bt var aizawi (xentari WG) and neem seed oil gave the highest reduction on $S$. littoralis.

\section{Latent effect:}

\subsection{Larval and pupal durations:}

Data presented in Table ( 3 and 4 ) demonstrated the residual effect of the three tested compounds (Spinosad, Dipel $2 x$ and Protecto) reflected the biological activities of $S$. littoralis. The feeding of both $2^{\text {nd }}$ and $4^{\text {th }}$ instar larvae on treated cotton leaves after 14 days of the three compounds, increased the larval duration. The effect was more pronounced with the $2^{\text {nd }}$ instar treated with the three compounds mixed sesame oil. The larval duration showed highly significant $(p<0.01)$ increase to average $18.2,18.1$ and 16.6 days for the three compounds, respectively, compared to 13.9days of control 
(untreated $2^{\text {nd }}$ instar larvae). Also, the treatment of $4^{\text {th }}$ instar larvae with the same compounds mixed with sesame oil highly significant $(p<0.01)$ increase, the larval duration was $16.8,17.8$ and 17 days, as compared to 12.6 days of the check. While $2^{\text {nd }}$ and $4^{\text {th }}$ instar larvae feeding on Spinosad, Dipel $2 x$ and Protecto combined with cotton seed oil at leaf residues aged 14days induced the next significant increase $(p<0.05)$ in the larval duration was $16.7,16.6,16.9$ and $16.5,17.3$ and 16.7 days, respectively, compared to 13.9 and 12.6 days of the control. Whereas, the $2^{\text {nd }}$ and $4^{\text {th }}$ instar larvae treated with the three compounds mixed with soybean oil after 14 days revealed the following increase in the larval duration to average 16.4, 16.3, 16.2 and 16.2, 17 and16.4days, respectively. While, the $2^{\text {nd }}$ and $4^{\text {th }}$ instar larvae treated with the spinosad, Dipel $2 x$ and Protecto alone at 14days of the treatment gave less increase of larval duration to average $16,15.8,15$ and $16.4,13.9$ and 15 days,as compared to that of control.

On the other hand feeding the $2^{\text {nd }}$ and $4^{\text {th }}$ instar larvae on the treated leaves after 14 days of spray of the three compounds alone or their mixtures with sesame, cotton seed and soybean oils gave highly significant $(p<0.01)$ increase of pupal duration (Table 3 and 4). The effect was more pronounced with the $2^{\text {nd }}$ instar treated with the three compounds combined to sesame oil. It caused highly significant $(p<0.01)$ increase in the pupal duration, while pupal duration was 23, 28.4 and 26.6 days, respectively, compared to 9.9 days of control. In addition, the larval treatment of $4^{\text {th }}$ instar with the same compounds mixed with sesame oil highly significant $(p<0.01)$ increase the pupal duration, it was 22.8, 23.8 and 25.6 days, respectively, compared was found in to 9.4 days of the check. While $2^{\text {nd }}$ and $4^{\text {th }}$ instar larvae fed on Spinosad, Dipel $2 x$ and Protecto combined with cotton seed oil at treated leaves after 14 days of application induced the next significant increase in the pupal duration to 22,28 and 25.7 and $22.2,22.9$ and 25.4 days, respectively, in comparison with control (9.9 and 9.4days). Whereas, the $2^{\text {nd }}$ and $4^{\text {th }}$ instar larvae treated with the three compounds mixed with soybean oil after 14 days induced increase in the pupal duration to average $21,27.4,21.3$ and $21.2,21.6,23.8$ days, respectively. While, the $2^{\text {nd }}$ and $4^{\text {th }}$ instar larvae treated with the spinosad, Dipel $2 x$ and protecto alone after 14 days of the treatment gave less or none increase of larval duration to average 19.5, 9, 10.2 and 19.9, 7.89 .1 days, as compared to that of control.

The obtained results agree with those obtained by Morillo and Notz (2004) found that the duration of the larval and pupal stages and the developmental period from egg to adult of $S$. frugiperda was significantly longer in the lambdacyhalotrin-selected strain and the methomyl-selected strain compared to the control strain, from the first to the last generation. Ahmed (2004) mentioned that the larval period was elongated and the pupal period shorted for the new hatched larvae of pink and spiny bollworms, (Laboratory strain) treated with the higher concentrations of Spinosad when compared with untreated larvae. 
Table 3. Latent effect of the tested bioinsecticides and their combination with vegetable oils against $S$. littoralis treated as $2^{\text {nd }}$ instar larvae, under field laboratory conditions.

\begin{tabular}{|c|c|c|c|c|c|c|c|c|}
\hline \multirow[t]{2}{*}{ Treatment } & \multirow[t]{2}{*}{$\begin{array}{l}\text { Larval duration } \\
\text { (days) Mean } \pm \text { SD }\end{array}$} & \multirow[t]{2}{*}{$\begin{array}{c}\text { Malfo. larvae } \\
\%\end{array}$} & \multicolumn{2}{|c|}{$\begin{array}{c}\text { Pupation } \\
\%\end{array}$} & \multirow{2}{*}{$\begin{array}{c}\text { Pupal } \\
\text { Duration (days) } \\
\text { Mean } \pm S D\end{array}$} & \multirow{2}{*}{$\begin{array}{l}\text { Pupal weight } \\
(\mathrm{mg}) \\
\text { Mean } \pm \text { SD }\end{array}$} & \multicolumn{2}{|c|}{$\begin{array}{c}\text { Adult emergence } \\
\%\end{array}$} \\
\hline & & & Normal & Malfo. & & & Normal & Malfo. \\
\hline Spinosad24SC & $16.0+0.4 * *$ & 0 & $63.4^{* *}$ & 0 & $19.5+0.5 * *$ & $260+7.8^{* *}$ & $89.8 \mathrm{n} . \mathrm{s}$ & 10.2 \\
\hline S+cotton oil & $16.7 \pm 2.5 * *$ & 0 & $20 * *$ & 5 & $22 \pm 1.6 * *$ & $252 \pm 6.8^{* *}$ & $76.9 * *$ & 23.1 \\
\hline S+sesame oil & $18.2 \pm 2.5 * *$ & 0 & $11.8^{* *}$ & 7.7 & $23 \pm 3.6 * *$ & $207 \pm 47 * *$ & $62 * *$ & 38 \\
\hline S+ soybean oil & $16.4 \pm 0.8^{* *}$ & 0 & $23.5^{* *}$ & 3.3 & $21.0 \pm 1.2$ & $258 \pm 36 * *$ & $85.2^{*}$ & 14.9 \\
\hline Dipel $2 \times 6.4 \mathrm{Wp}$ & $15.8+1.3 * *$ & 0 & 100n.s & 0 & $9+1.6 n \cdot s$ & $350+46 n . s$ & 100n.s & 0 \\
\hline $\mathrm{D}+$ cotton oil & $16.6 \pm 0.9 * *$ & 0 & $40 * *$ & 3.6 & $28 \pm 0.7$ & $242 \pm 1.2^{* *}$ & $88.9 n .5$ & 11.1 \\
\hline D+ sesame oil & $18.1 \pm 2.3^{* *}$ & 13.3 & $24.5^{* *}$ & 4.2 & $28.4 \pm 0.6^{* *}$ & $226 \pm 45^{* *}$ & $80.0^{* *}$ & 20 \\
\hline D+ soybean oil & $16.3 \pm 0.7 * *$ & 6.7 & $45^{* *}$ & 3.4 & $27.4+2.2$ & $244 \pm 41^{* *}$ & $87.5 n .5$ & 12.5 \\
\hline Protecto9.4Wp & $15.0+2.1^{* *}$ & 0 & 100n.s & 0 & $10.2+1.8 \mathrm{n} . \mathrm{s}$ & $267 \pm 8.2^{* *}$ & $91.7 n . s$ & 8.3 \\
\hline $\mathrm{P}+$ cotton oil & $16.9 \pm 1.4 * *$ & 6.7 & $44 * *$ & 9.6 & $25.7 \pm 2.7 * *$ & $248 \pm 61^{* *}$ & $85.7 n . s$ & 14.3 \\
\hline$P+$ sesame oil & $16.6+1.2^{* *}$ & 13.3 & $36 * *$ & 12.5 & $26.6+3.0 * *$ & $232+46 * *$ & $77.5^{* *}$ & 22.5 \\
\hline $\mathrm{P}+$ soybean oil & $16.2+0.6 * *$ & 6.7 & $54 * *$ & 6.7 & $21.3+2$ & $261+34 * *$ & $86.7 n . s$ & 5.6 \\
\hline$P$ value & 0.001132 & & 0.0025 & & 0.0002 & 0.00064 & 0.00756 & \\
\hline L.S.D at 0.05 & 0.504167 & & 12.1 & & 0.75 & 64.3273 & 8.42 & \\
\hline 0.01 & 0.775833 & & 27.93 & & 1.02 & 100.7182 & 15.44 & \\
\hline
\end{tabular}

$* *$ = Highly Significant $(p<0.01)$

S.D. = Standard deviation

* Significant $(p<0.05)$

L.S.D. = Least significant difference Lab. = Laboratory strain

N. S=none Significant $(p>0.05)$ 
Table 4. Latent effect of the tested bioinsecticides and their combination with vegetable oils against S. littoralis treated as4th instar larvae, under field laboratory conditions.

\begin{tabular}{|c|c|c|c|c|c|c|c|c|}
\hline \multirow[t]{2}{*}{ Treatment } & \multirow{2}{*}{$\begin{array}{l}\text { Larval duration } \\
\text { (days) Mean } \pm S D\end{array}$} & \multirow[t]{2}{*}{$\begin{array}{c}\text { Malfo. } \\
\text { larvae \% }\end{array}$} & \multicolumn{2}{|c|}{$\begin{array}{c}\text { Pupation } \\
\%\end{array}$} & \multirow{2}{*}{$\begin{array}{c}\text { Pupal } \\
\text { Duration (days) } \\
\text { Mean } \pm \text { SD }\end{array}$} & \multirow{2}{*}{$\begin{array}{l}\text { Pupal weight } \\
(\mathrm{mg}) \\
\text { Mean } \pm \text { SD }\end{array}$} & \multicolumn{2}{|c|}{$\begin{array}{c}\text { Adult emergence } \\
\%\end{array}$} \\
\hline & & & Normal & Malfo. & & & Normal & Malfo. \\
\hline Spinosad24SC & $16.4 \pm 1.8 * *$ & 0 & 93.3n.s & 0 & $19.9 \pm 0.3 * *$ & $264 \pm 20 * *$ & 97n.s & 3 \\
\hline S+cotton oil & $16.5 \pm 0.9 * *$ & 0 & $37.5^{* *}$ & 3.6 & $22.2 \pm 1.9 * *$ & $233 \pm 15 * *$ & $88.5 n .5$ & 11.5 \\
\hline S+sesame oil & $16.8 \pm 1.7 * *$ & 0 & $36 * *$ & 3.6 & $22.8 \pm 4.8^{* *}$ & $206 \pm 71 * *$ & $80.7 * *$ & 19.3 \\
\hline $\begin{array}{l}\text { S+ soybean } \\
\text { Oil }\end{array}$ & $16.2 \pm 0.5^{* *}$ & 6.7 & $44 * *$ & 3.6 & $21.2 \pm 1.3^{* *}$ & $240 \pm 21 * *$ & $96.5 n . s$ & 3.5 \\
\hline Dipel2x6.4Wp & $13.9 \pm 1.8^{*}$ & 0 & 100n.s & 0 & $7.8+1.1^{* *}$ & $357 \pm 33 n . s$ & 100n.s & 0 \\
\hline D+ cotton oil & $17.3 \pm 3.2^{* *}$ & 0 & $74.5^{* *}$ & 0 & $22.9+1.1^{* *}$ & $228 \pm 45 * *$ & 84.9* & 15.1 \\
\hline D+ sesame oil & $17.8 \pm 3.8^{* *}$ & 0 & $63.4 * *$ & 0 & $23.8 \pm 1.6^{* *}$ & $207 \pm 56 * *$ & $76.7^{* *}$ & 23.3 \\
\hline D+ soybean oil & $17 \pm 3.7 * *$ & 0 & $80 * *$ & 0 & $21.6+1.8^{* *}$ & $229 \pm 35^{* *}$ & 100n.s & 0 \\
\hline Protecto9.4Wp & $15+2.1^{* *}$ & 0 & 100n.s & 0 & $9.1+1.6 n . s$ & $318 \pm 25^{*}$ & $93.8 \mathrm{n} . \mathrm{s}$ & 7.2 \\
\hline $\mathrm{P}+$ cotton oil & $16.7 \pm 2.2 * *$ & 0 & $74.5^{* *}$ & 9.1 & $25.4 \pm 3.4 * *$ & $228+22 * *$ & $91.7 n . s$ & 8.4 \\
\hline $\mathrm{P}+$ sesame oil & $17 \pm 1^{* *}$ & 0 & $70 * *$ & 13.4 & $25.6 \pm 1.5^{* *}$ & $226 \pm 46 * *$ & $80.6 * *$ & 19.4 \\
\hline P+ soybean oil & $16.4 \pm 1.3^{* *}$ & 0 & $80 * *$ & 3.7 & $23.8+3.1^{* *}$ & $282 \pm 16 * *$ & 92.9n.s & 7.1 \\
\hline Control & $12.6 \pm 0.5$ & 0 & 100 & 0 & $9.4 \pm 1.4$ & $375 \pm 26$ & 100 & 0 \\
\hline F value & 391.3344 & & 2675.4 & & 1121.963 & 63.58834 & 22.375 & \\
\hline$P$ value & 0.0000013 & & 0.0023 & & 0.0000551 & 0.003755 & 0.01822 & \\
\hline L.S.D at 0.05 & 0.6658 & & 5.325 & & 0.975 & 45.02917 & 16.01 & \\
\hline 0.01 & 0.895 & & 12.288 & & 1.325 & 70.576 & 36.962 & \\
\hline
\end{tabular}

$* *$ = Highly Significant $(p<0.01)$

S.D. =Standard deviation

L.S.D. = Least significant difference

N. $S=$ none Significant $(p>0.05)$
* Significant $(\mathrm{p}<0.05)$

Malfo. = Malformation $\%$

Lab. =Laboratory strain 


\subsection{Pupation and Pupal weight:}

Data presented in Table ( 3 and 4 ) showed that the $2^{\text {nd }}$ and $4^{\text {th }}$ instar larvae of $S$. littoralis fed on treated cotton leaves after 14 days of application with Spinosad, Dipel $2 x$ and Protecto alone or in combination with sesame, cotton seed and soybean oils. There was highly significant $(p<0.01)$ decrease in the pupation percentage in respect to control. The effect was more pronounced with the treatment of the three compounds combined with sesame oil. The pupation percentages were 11.8, 24.5 and $36 \%$, respectively of $2^{\text {nd }}$ instar, and it were $36,63.4$ and $70 \%$, respectively, of $4^{\text {th }}$ instar, compared to $100 \%$ of control. Whereas, the larval feeding of the $2^{\text {nd }}$ and $4^{\text {th }}$ instar larvae with treated leaves with the three compounds in combination with cotton seed oil had next effect in pupation decrease to reach 20, 40, 44 and 37.5, 74.5, 74.5 $\%$, respectively. While, the larval treatment of both instars with the three compounds in combination with soybean oil had the least effect on pupation, it decreased the pupation $\%$ to $23.5,45,54$ and $44,80,80 \%$, respectively, compared to check $(100 \%)$. Consequence, the larval treatment of $2^{\text {nd }}$ and $4^{\text {th }}$ instar with Spinosad, Dipel $2 x$ and Protecto caused the lowest effect in pupation decrease to be 63.4, 100,100 and $93.3,100,100 \%$, respectively, compared to $100 \%$ pupation of control.

Likewise, the larval feeding of $2^{\text {nd }}$ and $4^{\text {th }}$ instar larvae on the treated leaves after 14 days of spray of the three tested compounds highly significantly $(p<0.01)$ reaction in the pupal weight was found of the resulted pupae. The $2^{\text {nd }}$ instar treated with the three compounds combined to sesame oil was the most suppressive one on the pupal weight, it decreased the pupal weight to 207,226 and $232 \mathrm{mg}$, respectively, compared to $365 \mathrm{mg}$ of the untreated $2^{\text {nd }}$ instar larvae. Whereas, the larval treatment of $4^{\text {th }}$ instar with the same compounds combined with sesame oil highly significant ( $p<0.01$ ) increased was obtained in the pupal weight to be 206,207 and $226 \mathrm{mg}$, respectively, compared to the control $(375 \mathrm{mg})$. While $2^{\text {nd }}$ and $4^{\text {th }}$ instar larvae fed on leaves treated with Spinosad, Dipel $2 x$ and Protecto combined with cotton seed oil at leaf after 14 days of treatment revealed significant decrease in the pupal weight to $252,242,248$ and 233, 228, $228 \mathrm{mg}$, respectively, compared to the control (365 and $375 \mathrm{mg}$ ). Whereas, the $2^{\text {nd }}$ and $4^{\text {th }}$ instar larvae treated with the three compounds in combination with soybean oil after 14 days induced decrease in the pupal weight to be $258,244,261$ and $240,229,282 \mathrm{mg}$, respectively. While, the $2^{\text {nd }}$ and $4^{\text {th }}$ instar larvae treated with the spinosad, Dipel $2 x$ and protecto alone after 14 days of the treatment induced low or none decrease of pupal weight to be 260, 350, 267 and 264, $357,318 \mathrm{mg}$, compared to control. 
The obtained results similar to that obtained by Ahmed (2004), who found that the average of pupation percentages for pink and spiny bollworms gradually decreased with increasing concentrations of the tested compounds (Agerin, Diple $2 x$ Naturalis L, Spinosad) in laboratory and field strains, respectively.

\subsection{Moths emergence:}

The larval feeding of $2^{\text {nd }}$ instar on treated cotton leaves with spinosad, protecto and Dipel $2 x$ compounds combined to sesame oil after 14days of the application gave highly significant $(p<0.01)$ decrease of the adult emergence to reache 62,80 and $77.5 \%$, respectively, as compared to $100 \%$ of control. While the larval feeding of the $4^{\text {th }}$ instar on spinosad mixed with sesame oil only induced the adult emergence decrease to reach $80.7,76.7$ and $80.6 \%$ in comparison the check (100\%). Similarly, the larval treatment of $2^{\text {nd }}$ instar with spinosad in combination with cotton oil induced $76.9 \%$, hence, the $4^{\text {th }}$ instar treated with Dipel $2 x$ combined to cotton seed oil and the $2^{\text {nd }}$ instar treated with Spinosad in combination with soybean oil caused significant $(p<0.05)$ decrease in the adult emergence to average 84.9 and $85.2 \%$, respectively, as compared to that of control (100\%).

These results are agree to those obtained with Ahmed (2004) who found that adult emergence for pink and spiny bollworms gradually decreased with increasing concentrations of the tested compounds (Agerin , Diple $2 x$ Naturalis $L$, Spinosad) in laboratory strain.

\subsection{Morphogenetic effects:}

Data presented in Table ( 3 and 4 ) demonstrated that the larval feeding of $S$. littoralis on the leaf residues of three compounds (Spinosad, Protecto and Dipel $2 x$ ) induced larval Deformation \% compared to control. The larval treatment of the $2^{\text {nd }}$ instar larvae with both Dipel $2 x$ and Protecto in combination with sesame oil gave the highest percentage of larval malformation reached $13.3 \%$, respectively, as compared to $0 \%$ of control. While the $2^{\text {nd }}$ instar treated with both dipel $2 \times$ and protecto in combination with soybean oil and the larvae treated with Protecto in combination with cotton seed oil induced $6.7 \%$. (Table 3 ). Also, the treatment of $4^{\text {th }}$ instar larvae with Spinosad mixed with soybean oil induced the same percentage (6.7\%), (Table 4).

A similar effect demonstrated with the larval feeding of $S$. littoralis on the leaf residues of the three compounds resulted in increase in the pupal deformation percentage, as compared to the control $(0 \%)$. The larval treatment of the $2^{\text {nd }}$ with spinosad, Protecto and Dipel $2 x$ in combination with sesame oil showed the greatest percentage reached to $7.7,4.2$ and $12.5 \%$, respectively, as compared to $0 \%$ of the control. While the larval treatment with the three compounds in combination with 
cotton oil induced the next percentage, it reached 5, 3.6 and $9.6 \%$. Whereas, the larval treatment with three compounds combined to soybean oil gave the least percentage reached to3.3, 3.4 and $6.7 \%$.On the other hand, the larval treatment with the three compounds alone did not give any pupal malformation \%. While, the larval treatment of $4^{\text {th }}$ with Spinosad in combination with the three vegetable oils induced $3.6 \%$.Whereas, the $4^{\text {th }}$ instar treated with the three vegetable oils gave more higher reached to $9.1,13.4$ and $3.7 \%$, respectively, as compared o that of control.

Treatment of the $2^{\text {nd }}$ instar larvae with the three vegetable oils separetly or in combination with tested compounds revealed the highest percentage of malformed adults ranged between $11.2-38.23 \%$ compared to $0 \%$ of control. While the larval

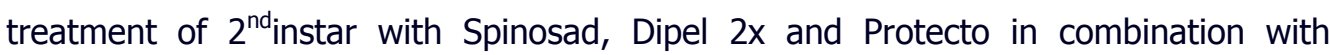
soybean oil gave $14.9,12.5$ and $5.6 \%$, respectively. Also, the $4^{\text {th }}$ instar treated with the three compounds in combination of sesame and cotton oils induced the greatest percentage of adult malformations reached to19.3, 11.5, 23.3, 15.1, 19.4 and8.4\%, respectively. Whereas, the $4^{\text {th }}$ instar treated with the three compounds in combination with soybean oil induced the least percentage reached to $3.5,0,7.1 \%$, respectively, compared to control.

Deformation of $S$.littoralis pupae resulting from the larval treatment of the $2^{\text {nd }}$ and $4^{\text {th }}$ instars with spinosad, protecto and Dipel $2 x$ in the present work mostly appeared as Malformed larvae appearing shortened and black (Fig.1) or Undersized larvae Fig.2 and 3) or larval-pupal intermediates (Fig.4, 5, 6, 7, 8 and 9) or Malformed pupae were unable to cast the last moulting (Fig.10) or Undersized pupae or abnormal pupae in shape (Fig.11, 12 and 13), as compared to normal pupae (Fig.14). Moreover, moth malformations showing completely absent of one of pair of wings and strongly malformed body (Fig.15) or Slight malformation in both wings (Fig.16) or Morphological varieties of malformed body and wings (Fig.17, 18 and 19), as compared to normal adults ( Fig.20). 


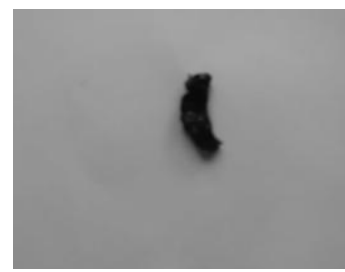

(Fig.1): deformed larvae appearing shortened and black
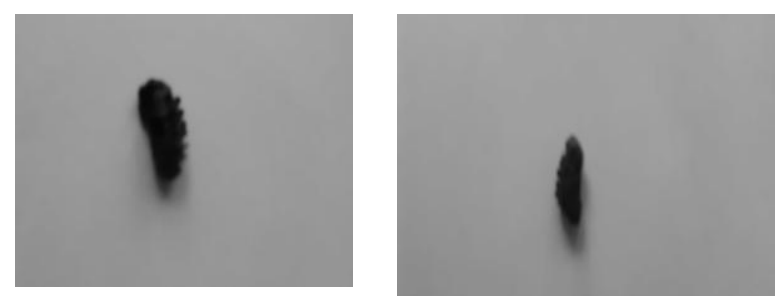

(Fig.2, 3): Undersized larvae
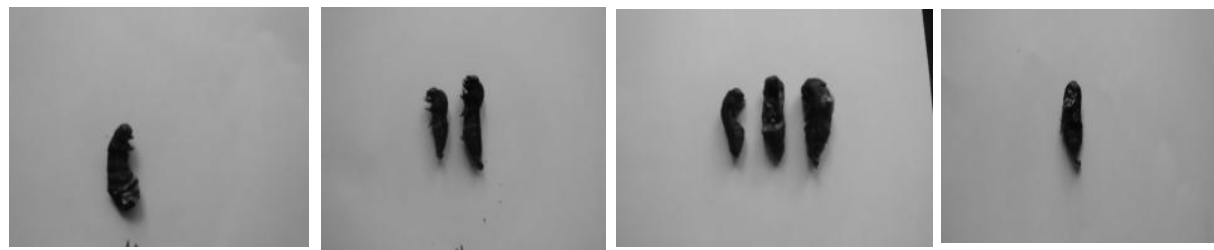

(Fig.4, 5, 6, 7, 8 and9): Larval-pupal intermediates

(Fig.10):deformed pupae were unable to cast the last moulting skin
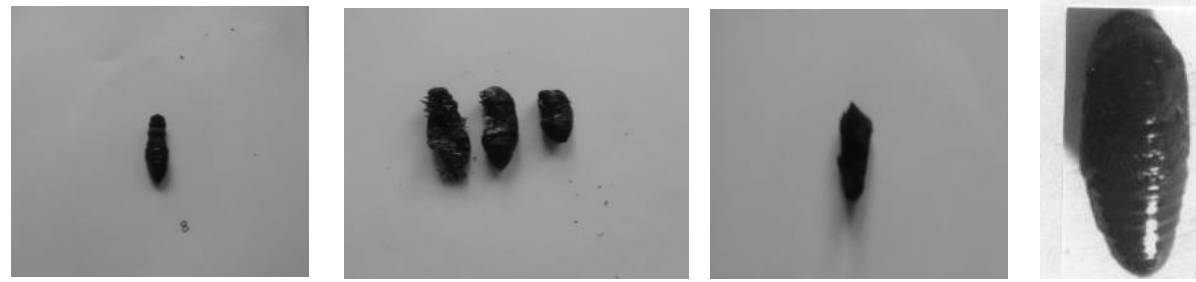

(Fig.11, 12and13): Undersized pupae or abnormal pupae in shape

(Fig.14)

Normal

pupae of $S$

.littoralis
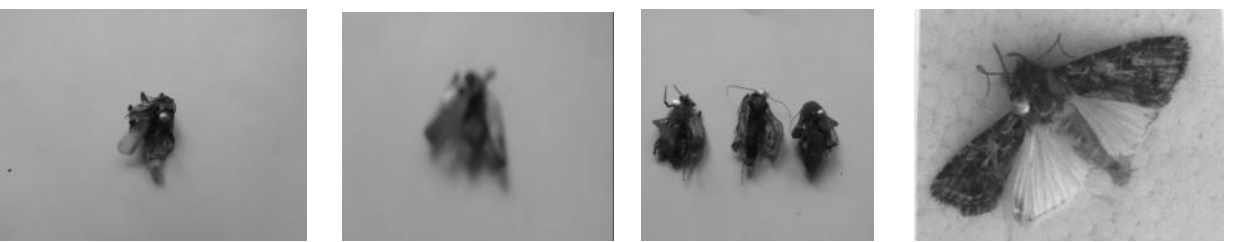

(Fig.15): Completely absent of one of pair of wings and strongly malformed bodv.

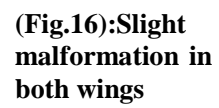
malformation in both wings

(Fig.17, 18 and 19):

Morphological

varieties of

malformed body
(Fig.20): Normal adult of $S$.littoralis

These results are agreement to those obtained by Ahmed (2004), who reported that Spinosad gave malformed pupal and adults in both laboratory and field strains of both Pink and Spiny bollworms. 
Table 5. Latent effect of the tested bioinsecticides and their combination with vegetable oils against $S$. littoralis treated as 2 nd and 4thinstar larvae, under field laboratory conditions

\begin{tabular}{|c|c|c|c|c|c|}
\hline \multirow[t]{2}{*}{ Treatment } & \multirow{2}{*}{$\begin{array}{c}\text { Fecundity } \\
\text { Eggs/female } \\
\text { Mean } \pm \text { SD }\end{array}$} & \multirow{2}{*}{$\begin{array}{c}\text { Fertility } \\
\% \\
\text { Eggs/f }\end{array}$} & \multirow[t]{2}{*}{$\begin{array}{l}\text { Longevity } \\
\text { Mean+SD }\end{array}$} & \multicolumn{2}{|c|}{$\begin{array}{c}\text { Adult emergence } \\
\%\end{array}$} \\
\hline & & & & Male & female \\
\hline Spinosad24SC & $50 \pm 30 * *$ & 100 & $11.5 \pm 1.7^{* *}$ & 50 & 50 \\
\hline S+cotton oil & zero** & zero & $8.3 \pm 1.4 * *$ & 52 & 48 \\
\hline S+sesame oil & $19.3 \pm 10 * *$ & 100 & $7.7 \pm 1.1^{* *}$ & 59 & 41 \\
\hline S+ soybean oil & $45+3.8^{* *}$ & 100 & $11.4 \pm 1.8^{* *}$ & 50 & 50 \\
\hline Dipel2x6.4Wp & $79 \pm 21 * *$ & 100 & $9.9 \pm 0.3 * *$ & 45.8 & 54.2 \\
\hline$D+$ cotton oil & $20.2 \pm 2.3^{* *}$ & 100 & $8.4 \pm 2.3 * *$ & 56.5 & 43.5 \\
\hline D+ sesame oil & zero** & zero & $8.3 \pm 0.6 * *$ & 54.5 & 45.8 \\
\hline D+ soybean oil & zero** & zero & $9.3 \pm 1 * *$ & 53.3 & 46.7 \\
\hline Protecto9.4Wp & $140 \pm 10 * *$ & 100 & $10.1 \pm 1.5^{* *}$ & 47.1 & 52.9 \\
\hline $\mathrm{P}+$ cotton oil & $105 \pm 5^{* *}$ & 100 & $8.5 \pm 4 * *$ & 56 & 44 \\
\hline $\mathrm{P}+$ sesame oil & $63 \pm 0.7 * *$ & 100 & $7.9 \pm 2.0 * *$ & 58.8 & 41.2 \\
\hline $\mathrm{P}+$ soybean oil & $93 \pm 7.5^{* *}$ & 100 & $9.6 \pm 1.5^{* *}$ & 56 & 44 \\
\hline Control & $649+144$ & \multirow[t]{5}{*}{100} & $15.5+1.8$ & \multirow[t]{5}{*}{50} & \multirow[t]{5}{*}{50} \\
\hline$F$ value & 147.8932 & & 221.6544 & & \\
\hline$P$ value & .00707 & & .000016 & & \\
\hline L.S.D at $\quad 0.05$ & 191.0955 & & 0.995833 & & \\
\hline 0.01 & 441.8282 & & 1.3425 & & \\
\hline \multicolumn{3}{|c|}{$k *=$ Highly Significant $(p<0.01)$} & \multicolumn{3}{|c|}{$*$ Significant $(p<0.05)$} \\
\hline \multicolumn{3}{|c|}{ S.D. =Standard deviation } & \multicolumn{3}{|c|}{ Malfo. = Malformation $\%$} \\
\hline \multicolumn{2}{|c|}{$\begin{array}{l}\text { L.S.D. = Least significant differen } \\
\text { N. } S=\text { none Significant }(p>0.05)\end{array}$} & \multicolumn{3}{|c|}{ Lab. = Laboratory strain } & \\
\hline
\end{tabular}

\subsection{Adult fecundity and fertility:}

Data presented in Table (4and 5) demonstrated that the larval feeding of $S$. littoralis on the leaf residues of the three compounds (Spinosad, Dipel $2 x$ and Protecto), highly significant $(p<0.01)$ reduced the adult fecundity in respect of control. The larval treatment of $4^{\text {th }}$ instar with Spinosad combined to cotton seed oil, and Dipel $2 x$ combined with sesame or soybean oils had the strongest effect on the adult fecundity, it completely inhibited the eggs laying (0.0), as compared to 649 eggs/ females of control. While the total number of eggs laid by adult females fed, as $4^{\text {th }}$ instar larvae on Spinosad combined to sesame oil and Dipel 2x with cotton oil gave19.3 and 20.2 eggs/ females, respectively, as compared to control. On the other hand, the total number of eggs laid by adult females treated as $4^{\text {th }}$ instar larvae with Spinosad mixed with soybean oil and Protecto with sesame oil or soybean oil had the next effect in adult fecundity reduction to average 45, 63 and 93 eggs/ females, respectively, as compared to that of control (649 eggs/ females).Whereas, the larval 
treatment with the three compounds, alone recorded the highest number of eggs(50,79 and 140eggs/female,respectively), as compared to that of control.

Likewise, the larval feeding of $S$. littoralis on the leaf residues of the three compounds (Spinosad, Dipel $2 x$ and Protecto), highly significant $(p<0.01)$ reduced the eggs hatching in respect of control. The larval treatment of $4^{\text {th }}$ instar with Spinosad combined to cotton oil, and Dipel $2 x$ combined to sesame or soybean oils had the strongest effect on eggs hatchability, it completely inhibited the eggs laying and hatching (0.0), as compared to $100 \%$ of control. While the total number of eggs hatching laid by adult females fed as $4^{\text {th }}$ instar larvae on Spinosad combined to sesame or cotton oil , or Dipel $2 x$ combined to cotton seed oil or Protecto combined to the three vegetable oils didn't' affect on the eggs hatching (100\%), as compared to that of control.

\subsection{Adult longevity:}

Data presented in Table (4 and5) showed that feeding of the $4^{\text {th }}$ instar larvae on the leaf residues aged 14 day sprayed with Spinosad, Dipel $2 x$ and Protecto alone or in combination with the three vegetable oils highly significant $(p<0.01)$ decreased the adult longevity of $S$. littoralis. The larval treatment of $4^{\text {th }}$ instar larvae treated with Spinosad, Dipel $2 x$ and Protecto in combination with sesame oils induced the shortest period of adult longevity to average7.7, 8.3 and 7.9 days, as compared to15.5days of the check.Whereas, the larval treatment with the three compounds combined to cotton oil induced the latent effect, it decreased the adult longevity to average8.3, 8.4 and 8.5days, and the larvae treated with the three compounds in combination with soybean oil had the least effect, it gave 11.4, 9.3 and 9.6days, and it averaged 11.5, 9.9 and10.1days for adult treated as $4^{\text {th }}$ instar with Spinosad, Dipel $2 x$ and Protecto alone, respectively, as compared to that of the check.

\subsection{Adult sex ratio:}

Data in Table (4 and 5) indicated that the $2^{\text {nd }}$ and $4^{\text {th }}$ instar larvae of $S$. littoralis fed on the leaf residues sprayed with Spinosad, Dipel $2 x$ and Protecto alone or in combination with the three vegetable oils shifted the adult sex ratio in respect to that of the control. It found that the larval treatment of $4^{\text {th }}$ instar with Protecto combined to Sesame oil had the highest effect in adult males increase to reach $58.8 \%$, as compared to $50 \%$ of males of control, and decreased the adult females to $41.2 \%$, as compared to $50 \%$ of adult females. While, the larval treatment with Protecto combined to both cotton seed and soybean oils had the latent effect in adult males increase to reach $56 \%$ and decreased the adult females to reach $44 \%$, as compared to that of control (50:50). On adversely, the larvae treated with the Protecto alone decreased the adult males to reach $47.1 \%$ and increase the adult females to reach 
$52.9 \%$,as compared to control (50:50).Also, the larval treatment of $4^{\text {th }}$ instar with Dipel $2 x$ combined with sesame and cotton oil induced the strongest effect in adult males to reach 54.5 and $56.5 \%$,respectively, and decreased the adult females to reach 45.8 and $43.5 \%$,respectively. Whereas, the larvae treated with Dipel $2 x$ combined with soybean oil induced the next effect in adult males increase to53.3 and decreased the adult females to $46.7 \%$,Hence, the larval treatment with Dipel $2 x$ alone decreased the adult male to $45.8 \%$, and increased the adult females to $54.2 \%$,as compared to control. On the other hand, the larval treatment with Spinosad combined to Sesame and cotton oils

induced the highest effect in adult males increase to reach 59 and52\%, and decreased adult females 41 and $48 \%$, respectively, Hence, the larval treatment with Spinosad

combined to soybean or Spinosad alone did not affect the sex ratio of both males and females.

\subsection{Reviewing the obtained results:}

Field studies suggest that, adding vegetable oils enhancing microbial insecticides performance and useful addition for controlling $S$. littoralis reducing the costs of pest control and environmental contamination.

\section{REFERENCES}

1. Abbott, W. S. 1925. A method of computing the effectiveness of an insecticide.J.Econ.Entomol, 18:265- 267.

2. Abdel-Hafez, H.F and M.A.Abdel-Aziz.2010.Synergistic effects of some plant Extracts to Biorational product, Spinosad against the cotton leafworm, S. littoralis. Egypt J. Biol. Pest control. 20 (1).27-32

3. Abdel-Mageed, A.M, E.M.Anwar, L.R.Elgohary and H.F.Dahi.2006.Field efficiency of the novel biocide, Spinosad singular and mixed with different groups of insecticides on cotton leafworm, S. littoralis. Bull.ent.Soc .Egypt. Econ. Ser., 32:91-99.

4. Abhilsh, C.and R. H. Patil. 2006.Comparative efficacy of new insecticides, botanicals and insect growth regulators against the pod borer complex and Soybean. Soybean Res., 4:69-72.

5. Ahmed, E. M. 2004. New approaches for control of cotton bollworms. Ph.D Thesis, Faculty of Agric. Cairo Univ.

6. Anonymous 1979. World Health Organization (WHO).Specifications for pesticides used in public health. $4^{\text {th }}$ ed, Geneva, 333pp. 
7. Bode, L. E., B. J. Bufler and C. E. Georing 1976. Spray thickener nozzle type and nozzle pressure, Trans.ASAE, 75:213-218.

8. El-Moursy, A. A., A.Sharaby and H. H. Awad. 1996. Some chemical additives to increase the activity spectrum of Bt var.Kurstaki (Dipel 2x) against Corcyra cephalonica. Bull. National. Res.Centre.Cairo21 (2).161-172.

9. Gringorten, J. L., R.E.Mile, P.E.Fast, S. S. Soho and K. Vanframdenhgzen. 1992. Suppression of Bacillus thuringiensis d-endotoxin activity by low alkaline PH. J, Invert. Pathol, 60:47-52.

10. Grovena, S., A. C. Santos, J. L.Silva, S. R.Benvenga and A. C. Caetona 2002. Effect of doses of Spinosad mixed with mineral oil to control citrus leafminer. Laranja, 23(1):155-165.

11. Hafez, H., H. S. Salama, R. About-Ela and M.Ragael 1987. Evalution of adjuvants for use with Bt vs. Heliothis armigera. Z. ang. Ent, 103, 313-319.

12. Ibrahim, M. A., G., Natalya, J.mattnew and B.Lee. 2010. Bt. Agenomics and proteomics perspective.Bio eng.Bugs.1 (1):31-51.

13. Mahmoud, B. A. 2004. Spinosad as a new biopesticide against the greasy cutworm, Agrotis ipsilon (Hnuf.).Agric. J. Suez Canal Univ., 4:137-141.

14. Moar, J. W., W.A.Osbrink and J. T. Trumble. 1986. Potentiation of Bacillus thuringiensis subsp.kurstaki with thuringiensim on beet armyworm (Lepidoptera: Noctuidae). J. Econ. Entomo 79:1443-1446.

15. Morillo, F. and A. Notz. 2004. Effect of lambdacyhalotrin and methomyl on the biology of Spodoptera frugiperda (Smith) (Lepidoptera: Noctuidae). Entomotropica (ISSN: 1317-5262) vol. 19 No. 1.

16. Morris, O. N., M. Trottier, V. Converse and P. Kanagaratnam. 1996. Toxicity of Bacillus thuringiensis subsp. Aizawal for Mamestra configurata. J. Econ. Entomol, 89 (2): 359-365.

17. Robredo, F. and E. Obama. 1987. Soybean oil as ULV carrier in forest spraying using Bt. Mededlingen Van-de-Fac. Land. Rijk. Gent. 52 (2b):757-762.

18. Temerak, S. A. 2003. Different susceptibility of pink bollworm, to the ova-larvicidal vactivity of Spinosad, a natural metabolites of Actinomycetes, Saccharopolysporo spinosa with special reference to solve the field failure of Thiodicarb in the current resistance rotation spraying program in Egypt, Res. Pest. Mon. 13(1):1-7.

19. Thompson, G. and S. Hutchins. 1999. Spinosad (Pesticide outlook).Dow Agroscience LLC, USA, 10 (2):78-81.

20. Turanili, F. E. Gumus and B. Guzel. 2012. Studies on the efficacies of combination of Bt with neem extracts.Turkiye.Entomol.Der.36 (3):433-439. 


\section{تأثير بعض الزيوت النباتية في زيادة فعالية

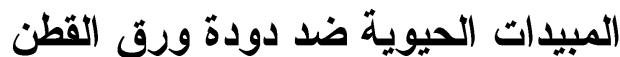

حنان فاروق السيد، الهام فاروق محمود عبد الرحيم، عصام محمد محمد

$$
\text { معهر بحوث وقاية النباتات - مركز البحوث النزراعية }
$$

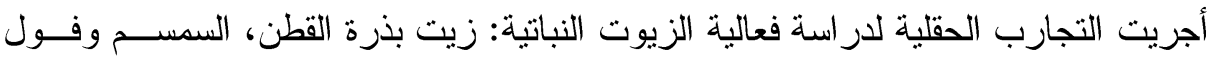

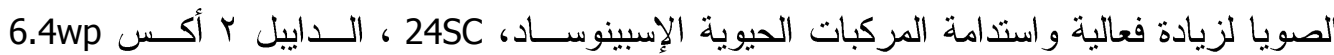

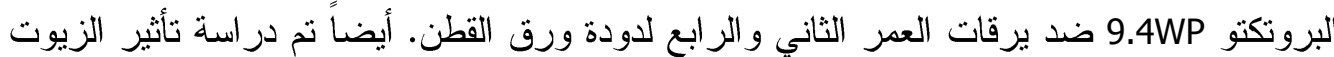
النباتية على الخواص الطبيعية - الكيماوية [اختبار التعلق - اللزوجة - درجة الأس الهيدروجيني ]

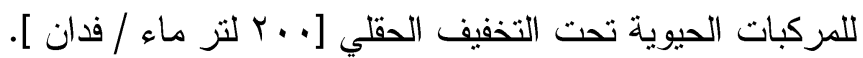

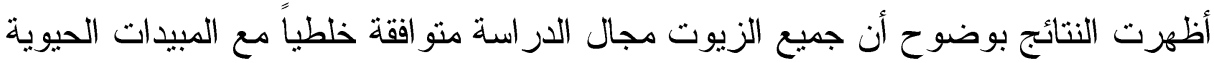
حيث أعطت معلق متجانس، هذا بالإضافة إلى زيادة لزوجة ودرجة الحموضة لهذه المركبات وسجل

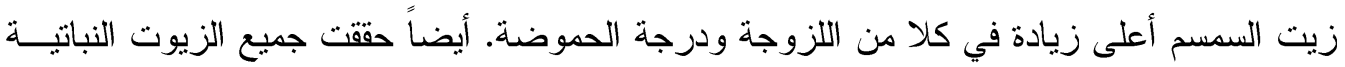

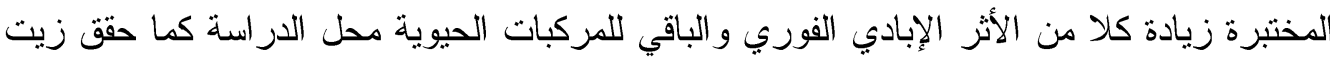

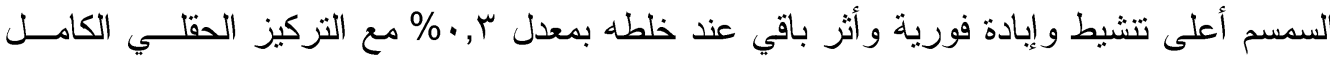

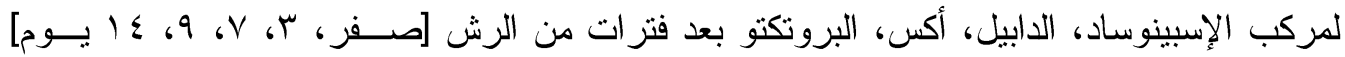

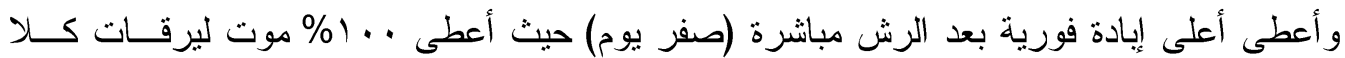

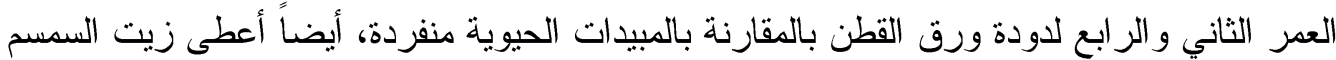

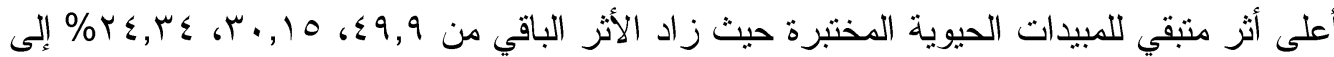

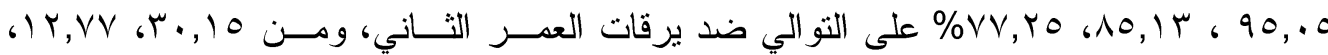

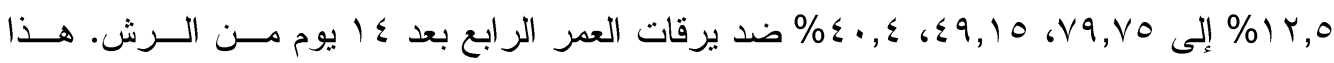

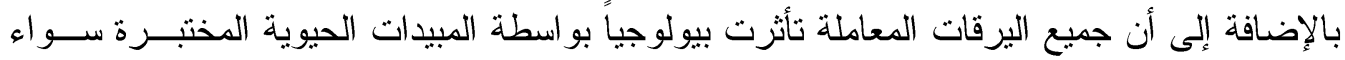

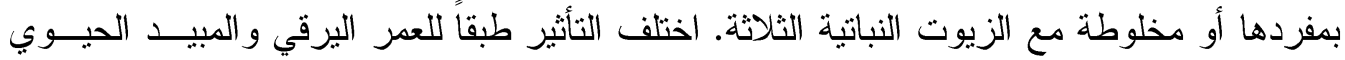

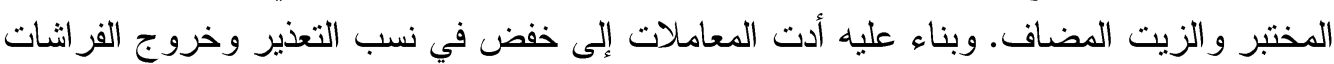

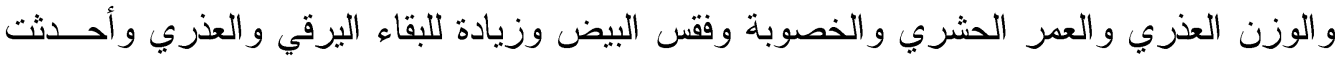
تشو هات برقية وعذرية وحشرية وأخلت بالنسبة الجنسية للذكور والإناث بالمقارنة بغيـر المعامـلـل

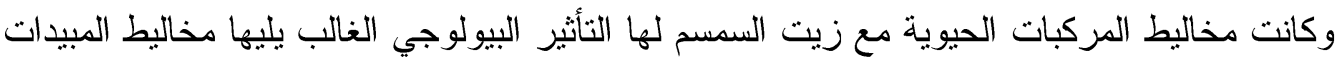
مع زيت بذرة القطن بينما احتل زيت فول الصويا الترتيب الأخبر. ويعزي هذا التأثثر التنشيطي إلى أن إضافة مثل هذه الزيوت التئ النباتية إلى المركبات الحيوية

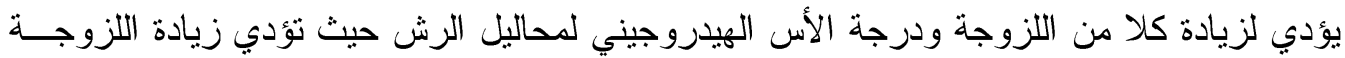

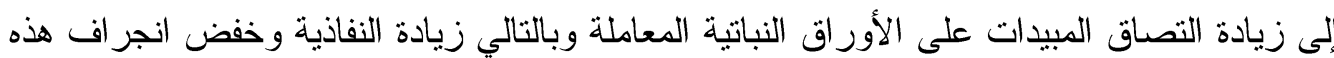

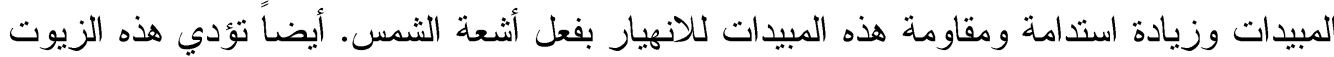

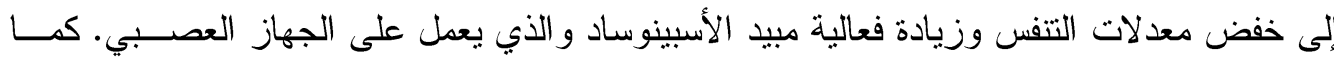

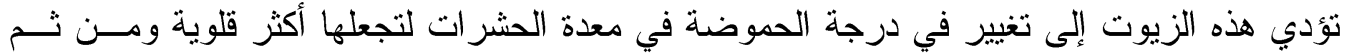

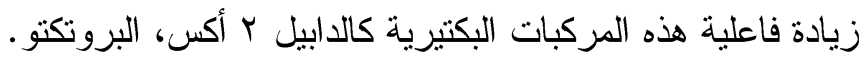

